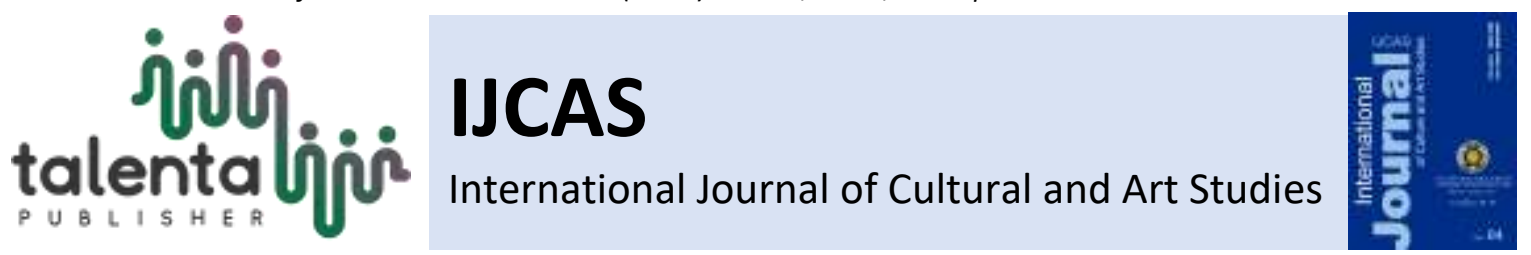

\title{
Possessive Expressions in Javanese
}

\author{
Kamilatun Baroroh ${ }^{1 *}$, Mulyadi $^{2}$ \\ 1,2, Master Program in Linguistics, Faculty of Cultural Sciences, University of Sumatera Utara, Medan, \\ Indonesia.
}

\begin{abstract}
This study aims to describe the characteristics of Possessive Construction in Javanese and relations of expressions between Possessor (PR) and Possessum (PS). The source of data are texts in Javanese from Djaka Lodang Magazine Volume XXII, XXIV, XXIX year 2017 and Panjebar Semangat Magazine Volume 29, 19, and 20 from May until July 2018 which contains Possessive Constructions in Javanese also informant who is a native speaker of Javanese. The data are analyzed using Simak Method, with base Sadap technic and advance Simak-Bebas libat cakap technic and Catat technic, meanwhile technic for analyzing the data used are Agih Method to determine the Possessive Construction dan Padan Method to determine the relation between PR and PM elements. Javanese Possessive Constructions marked with clitics $-e$ or $-n e$ as possessive marker. The results show Javanese Possessive Constructions meaning exists at polymorphemic level, phrase level, and clause level. On polymorphemic level, possessive meaning expressed by nouns followed by enclitics persona pronoun. On Phrase level, possessive meaning expressed by noun which followed by noun persona and noun followed by noun. Persona pronoun acts as PR. Noun which acts as PR are (Ilahi), animal, plants and (concrete) noun. On clause level possessive meaning expressed by verb which occupy predicate $(\mathrm{P})$. Noun occupying subject in clause recognized as possession (PM). In Javanese, it is found Possessive Construction which sates the relationship of proprietary in the form of; Possessive Construction in which PM elements is non-humane noun and PR elements is humane noun or persona pronoun, PM element is humane noun and PR element is humane (self-name) or persona pronoun, and PM element is non-living noun and PR element also non-living noun.
\end{abstract}

Keyword: Expressions, Expression of Possessive Relationships, Possessive Construction Received 02 April 2020 | Revised 16 April 2020 | Accepted 26 April 2020

\section{Introduction}

Possessive expressions are semantic symptoms that occur due to the relationship between two nouns that form FN and produce possessive meaning. The concept of possession in linguistics [1, 2,3 ] can be simply defined as the relationship between two entities namely the possessor (owner / PR) and possessum, possessed or possesses (owned / PR). In Indonesian possessive construction can be found in FN construction, 'my book', 'our class', 'sister's hand', 'father's house' [4, 5].

Possessive is an expression that has a variety of morphological and syntactic constructions in various languages [3]. Furthermore, Peters gives examples of possessive constructions in English as below.

\footnotetext{
${ }^{*}$ Corresponding author at: Master Program in Linguistics, Faculty of Cultural Sciences, University of Sumatera Utara, Jl. Abdul Hakim No.1 Medan, Indonesia.
} 
(1) a. (my / Mary's) (bicycles / books / hands / brothers)

b. (the) (bicycles / books / hands / brothers) of (mine / Mary's)

c. (several students' / each woman's (bicycles / books / hands / brothers)

d. (two / many) of (my / Mary's / several students' / each woman's) (bicycles / books / hands / brothers)

In addition, in Indonesian, possessive constructions can be repeated, producing sentences such as:

(2) Anak-anak kakakku sangat aktif.

Or in Javanese examples of possessive constructions like the following:

a. Omah sing gendhenge damaged kuwi, dituku Pak Lurah.

'The house with the damaged roof, was bought by the Village Chief'

b. Klambine adik, wis do sesak.

'Sister's clothes, already narrow'

c. Tanganku kena lading mau esuk.

'My hand was hit by a knife this morning'

Most of the examples above, show that the owner entity (PR) is a noun, such as Mary (name of person), klambi 'shirt' or pronoun (me). Furthermore, Storto [2] said that possessive expression is not just talking about two entities, but there are three components that must be explained in interpreting possessive relationships. The FN of my book, for example, must be explained with three components, namely the meaning of the book, my meaning, and the meaning of the relationship between the two. In other words, semantically, possessive meaning will include three components, namely owner's denotation, owned denotation, and possessive relationship between the two. Heine [7] describes seven types relating to the concept of ownership, namely (1) physical ownership, (2) temporal ownership, (3) permanent ownership, (4) irreversible ownership (5) abstract ownership, (6) ownership of irrevocable lifeless entities, and (7) ownership of transferred lifeless entities.

Possessive is a universal symptom. Every language has grammatical tools for expressing possessive relationships. But possessive expressions between languages are very likely to be different. In English possessive relationships can be expressed in adnominal constructions, for example my book, John's book. Both constructions have different PR categories, the first is my possessive pronouns, while the second is the self-name Jhon. This is very different in the possessive construction of the Indonesian language. The construction of my book and Andi's book, for example, between book nouns, can be directly followed by pronominal persona me and 
Andi. Although Andi and I are categorized differently, the difference between the two does not change possessive construction [8].

Regarding possessive relationships, Taylor [9] highlights six possessive relationships that may exist in possessive constructions.

- Family relationships (my nephew)

- The whole-part relationship (the dog's tail)

- The relationship between something and its attributes (my age)

- Authorship relationship (Shakespeare's play)

- Locative and temporal relationships (the city's residents, the day's event)

- The relationship between participants and events (the plane's departure)

In line with Taylor, Storto [2] also suggests that possessive relationships are quite diverse. He explained the diversity of possessive relationships with the following example.

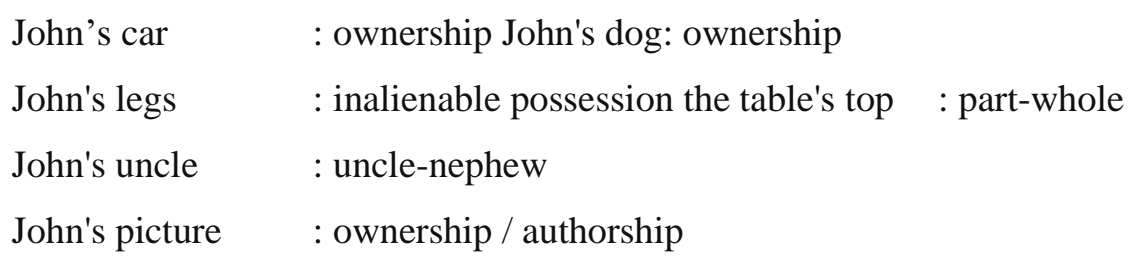

In the view of Boneh and Ivy [10] variation of possessive meaning is associated with differences in structure. That is the same as possessive structure will determine its possessive meaning. In such a context, possessive structures with the central elements of the noun categorized words with human and non-human characteristics generally will result in the meaning of part-whole relationships. This kind of construct is used to express the family relationship (for human beings) as mentioned above and the relationship between the part and the whole that is characterized by non-nature, for example the building and its parts.

Likewise Javanese, has its own construction in expressing ownership. There are possessive constructions in Javanese in the form of polymorphic words and phrases. The possessive construction in the form of polymorphic words is categorized by nouns (nouns as belonging and enclosed by me, mu-, - $e$ / -ne /-even as the owner). The possessive constructs in the form of phrases consisting of nouns function as the core status as belonging and other nouns as owners, can be filled with first, second, and third person pronouns, plural first person pronouns, persona kinship / self-names, and animate. Javanese possessive construction is characterized by the existence of clitic -e or -ne as possessive markers [11]. 
Example:

\section{a. Bocah kuwi nganggo topi tentara}

'The boy is wearing an army hat'.

\section{b. Bocah kuwi nganggo topine tentara, sing dhek wingi nginep kene.}

'The boy is wearing an army-Poss hat, who was staying overnight yesterday'.

Sentence 4 (a), the phrase of army hat, is an identifiative nominal phrase, which means 'hat used specifically for soldiers', and cannot be a phrase of ownership. Sentence 4 (b), after the phrase army hat is given clitic -ne in the word 'hat' the meaning changes to 'hat belongs to the army'.

Discussion about possessive construction in Javanese has been carried out by several researchers, but only limited to syntactic construction and a little about semantics which states that the element of the owner (possessor / PR) in possessive construction of Javanese includes divine, animal, noun (concrete objects), and plants [12]. This study aims to look at various possessive constructions in Javanese and how the characteristics of the relationship between PR and PM in possessive constructions in Javanese.

\section{Method}

The methods used in this study include data collection, data analysis, and data analysis exposure. Data sources are Javanese language texts from the magazines in Djaka Lodang magazine volume XXII, XXIV, XXIX in 2017 [13] and Panjebar Semangat volume 29, 19, 20 from May to July 2018 [14]. In addition to text, another data source is the informant by referring to the method, also based on the author's intuitive data which is a native speaker of Javanese. The data recorded is data relating to the possessive construction of the Javanese language.

In this study data collection process using the refer method by using the note-taking technique as a follow-up technique. The method of listening is done to observe the use of language. The term listening here is not only related to the use of language verbally, but also the use of written language. This method has a basic technique in the form of tapping techniques. The purpose of the tapping technique here is to tap the use of language, both verbally and in writing. In practice, the tapping technique is followed by advanced techniques, namely the technique of talking involved, the technique of free listening, the technique of free listening involved, and note taking technique. The listening method in this study uses an advanced technique in the form of note taking. The note taking technique is used as a technique in data collection. The note taking technique is to note some forms that are relevant to his research from the use of written language. Data were analyzed using the listening method, with the basic techniques of tapping techniques and advanced techniques used competent free listening and note taking techniques [15]. This 
study use the metode agih or distribution methods to process the data that has been obtained. The distributional method uses a determinant in the language itself. The basic determinant in the work of distributional methods is the technique of selecting data based on certain categories (criteria) in terms of programming in accordance with the natural characteristics of the research data.

\section{Results and Discussion}

This study discusses two main problems, namely possessive construction in Javanese and the relationship between PM and PR in possessive construction of Javanese. Based on the results of data analysis obtained from various data sources as mentioned earlier, we found several results related to the subject matter above.

\subsection{Construction of Javanese Possessive Expressions}

In Javanese, possessive expression is characterized by affixes -ne in open syllables and -e in closed syllables, both in person nouns and nonpersons [11]. Javanese uses the -e/-ne affix as a constituent coupling with its attributes whose function is not as an ownership pronoun. But Sudaryanto [16] explained that possessive possessors in Javanese are three, namely clitics $-k u$, $m u$ and $-e /-n e$. Clitic $-k u$ is the first-person possessive marker, -mu as the second person possessive marker, and $-e /-n e$ as the third person possessive marker.

In the plural form, kita persona is known as 'us', which is a combination of the first person and the second person. Javanese does not recognize other forms of plural than us, it is used in the form of phrases for other denominations. Like aku kabeh for the plural of the word 'we', and kowe kabeh for the plural of 'all of you / you'. Javanese does not recognize third (their) plural pronouns. Aside from being a marker of belonging, it turns out that in Javanese language, clitic -e / -ne also states the meaning of 'certain'[17].

Like the data found in the Djaka Lodang magazine below:

(5) a. Astirin ditinggal kancane sak kamar

'Astirin is left behind by Moss's roommate' (Astirin is left by her roommate).

b. Sesuk esuk akuarep tilik mbokdheku

Tomorrow morning, I will look at auntie-poss

'Tomorrow morning, I will see my aunt'

c. Wayahe wis mundak sore

The time (-e deterniner) is getting late

'The time is getting late'. 


\section{d. Dinane senin}

'Today is Monday'

The affixes -e / -ne in (5) a and b are possessive markers, whereas in (5) b and c, -e / -ne states 'certain' meanings.

Based on the data obtained constructive structure in Javanese language, namely, (1) possessive structure at the polymorphemic level, (2) possessive construction at the phrase level, and (3) possessive construction at the level of the clause.

\subsection{Construction of Javanese Possessive Expressions}

The possessive construction in polymorphemic level consists of nouns, which states that the property belongs to (PM) and the pronominal persona enclitic as the owner (PR). Includes first, second, and third person pronouns. There is only one first personal pronoun in Javanese, namely $k u$, an example of this is:
a. omahku 'my house'
b. tanganku 'my hand'
c. sisihanku 'my husband/wife'
d. anakku 'my son/girl'

Possessive construction consisting of nouns and pronominal second persona enclitic, there is also only one, namely $-m u$.
a. ритити 'your grandson'
b. klambimu 'your shirt'
c. jaranmu 'your horse'
d. karepmu 'your wish'

Possessive construction consisting of nouns and pronominal third persona enclitic, namely -e / ne.
a. ibune
'her/his mom'
b. sikile
'her/his feet'.

\subsection{Construction of Javanese Possessive Expressions}

The possessive construction at the phrase level can only be used in middle speech or manners. In the ngoko range of languages, this possessive construction cannot be used, because in the ngoko range the possessive construction must be followed by the pronoun enclitics. Some data obtained 
came from short stories (short stories) that use middle language in conversations with respected people. Javanese language is one of the languages that use unduk usuk language (level of language) used to regulate language politeness.

Possessive construction at the phrase level can be divided into two, namely (1) possessive construction consisting of nouns and pronominal persona. This possessive construction can only be used in middle speech or manners. In a variety of ngoko languages, this possessive construction cannot be used. Some of the data obtained, comes from short stories that use intermediate language in conversations with respected people, because Javanese is one of the languages that use undhak usuk language (level of language) used to regulate language politeness.

Example:
a. manah kula
'my heart'
b. ageman dalem
'my shirt'
c. biyung sira 'your mother'
d. anak ndika 'your child'
e. semahipun Lurah Sidoarum 'Lurah sidoarum's wife'.

But from the data (9), we get the phrase biyung sira 'your mother', which is known as a variety of ngoko, so for the word sira 'you', is one exception. Nowadays, the word sira is rarely used, except for written language, because in everyday language the word kowe is used. Second (2) possessive construction consisting of nouns and nouns, in this construction the noun in the front is acting as the owned / owned (PR) and the noun behind the owner (PM). Nominees that act as owners can be divided into five types, namely, (a) divine nouns, (b) human nouns, consisting of two parts (nouns and self-names; nouns and kinship names), (c) animal nouns, (d) nouns plants, and (e) noun objects.

Divine nouns in Javanese are words that declare for God. For example, Gusti Allah, Maha Agung, Maha Wikan, and others. While human nouns are words that express human or person. The human nouns in Javanese includes the name of self, name of kinship, name of position, and name of title. The human noun acts as the owner, while the noun as owned.

(10) a. Possessive construction consisting of nouns and self-names

$\begin{array}{ll}\text { sikile Amir } & \text { Amir's feet } \\ \text { omahe Suci } & \text { Suci's house }\end{array}$

b. Nouns and kinship names
bukune bapak
father's book
putrane paman
uncle's son 
c. Nouns and position nouns

$\begin{array}{ll}\text { mantune Lurah Dadapayu } & \text { 'the son-in-law of the head of Dadapayu' } \\ \text { Omahe dokter Puskesmas } & \text { 'Puskesmas doctor's house' }\end{array}$

d. Nouns and title nouns

$$
\text { dalemipun R.A. Kartini 'R.A. Kartini’s house' }
$$

Animal nouns are nouns that express the names of animals. Animal nouns as owners and nouns as owned.
a. Buntute kucingku
'my cat's tail'
b. Endog (-e) iwak
'fish egg'

from the above data the phrase closeness between PR and PM seems to be laxer, meaning clitic e / -ne is not mandatory. In the buntute kucingku phrase, for example, can form buntut kucing phrase without the presence of clitics $-e$ as a possessive marker. Likewise, with vegetable nouns, the closeness between PR and PM seems loose. Without the existence of clitics - $e$ / $-n e$ the noun phrases and plant nouns clearly state the possessive construction in Javanese.
a. Tlutuhe karet/ tlutuh karet
'rubber tree latex'
b. Godhonge gedang/ godhong gedang
'banana leaf'

The next construction is possessive construction consisting of nouns and nouns (inanimate objects). What is meant by an inanimate object is a noun that states the name of the type of objects. The object noun acts as the owner, and the noun who acts as the owner is the noun that states mandatory and certain.
a. Tegel omah
'house tile'
b. Lawang omah
'door of house'
c. Ban (-e) mobil
'car tires'

from the data above, the noun who acts as the owner who states the mandatory and certain part is located in front, precedes the noun as the owner. In the example above it also appears that the proprietary element which states a mandatory and certain part does not require the existence of clitics $-e /-n e$.

\subsection{Construction of Javanese Possessive Expressions}

A clause is a grammatical unit in the form of a group of words consisting of at least a subject and a predicate and has the potential to be a single sentence [17]. At the level of the clause, possessive 
meaning is expressed by verbs that occupy the predicate. Possessive verbs in Javanese include duwe, duweke, and nduweni.

$$
\begin{gathered}
\text { a. Aku duwe buku } \\
\text { I Poss. book } \\
\text { I have a book.' }
\end{gathered}
$$

\section{b. Sanajan dudu duweke dewe, Arin ngrumat buku kuwi temenanan.}

'Even though not his, Arin took good care of the book.'

\section{c. Labu air nduweni kasiyat kanggo obat lara pilek. 'Labu air Poss. efficacy for cold medicine.'}

\subsection{Construction of Javanese Possessive Expressions}

According to Storto [2] there are three components that must be explained in interpreting the possessive relationship in FN John's car, namely the meaning of John, the meaning of the car, and the meaning of the relationship between the two. The conclusion of these three components can be generalized as possessive construction. Based on the relationship between PM and PR found two types of relationships, namely family relations and property rights relationships.

\subsubsection{Family Relations}

Family relationships that arise from the relationship between PM and PR are marked with PM fillers in the noun category used for the designation of entities that have family relationships, such as children, wives, husbands. This relationship belongs to the lexical possessive category. In lexical possessiveness, the characteristics of PM filler elements determine the acceptability of the relationship between PM and PR [8].

From the data, found family relations in possessive Javanese language construction as follows:

(15) Sisihane Hartono wingi sore ditekani pulisi sing arep golek katrangan.

Wife-Poss Hartono yesterday afternoon was visited by the police who would look for information.

Hortono's wife visited by the police yesterday who was going to look for information.

(16) Sisihane Bu Zahza, Pak Riris, kepengin duwe momongan.

Husband-Poss Bu Zahra, Pak Riris, want to have a baby.

Ms. Zahza's husband, Mr. Riris, want to have a baby.

(17) Anakku wis mangkat menyang Jakarta mau esuk..

Child-Poss had left to Jakarta this

My son had left for Jakarta this morning. 
Sisihan and anak nouns as PM filling elements are words used to refer to entities that have family relations with the PR element. The characteristics of the PR fill element will determine the PM fill element. If examined more closely, the three PM filler elements are different. Wife nouns, husbands are different from child nouns. In the context of Indonesian culture in general, the wife's nouns are among the PM elements that are exclusive because they only allow the presence of a single homework. That is, a wife can only be "owned" by one owner. This is different from a noun with a character that can be owned by more than one owner.

Unlike the characteristics of a wife, the husband's noun characteristic allows more than one owner to have. That is, in Indonesian society there is the fact that a husband is owned by more than one owner (wife), even though this fact is for some people undesirable. In other words, there are husbands who have more than one wife. Conversely, it never happens that a wife has more than one husband.

The possessive construction that expresses the family relationship above is an element of PR filling that will always be in the category of human nouns. Pronouns $-k u$ or proper names used to refer to human entities, namely humans. The relationship between PM and PR above can be included in the inalienable possession category. That is, the PM element cannot be transferred to the others. In possessive studies, family relations such as the example above are categorized as permanent relationships, which do not allow between PR and PM to be separate or distracted. Such relationships are also used to describe the relationship between a person and body parts, for example tanganku is 'my hand'.

\subsubsection{Family Relations}

In Javanese, possessive construction is found which states the relationship of ownership in the form of (1) possessive construction in which the PM element is inanimate non-human nouns and the PR element is a human noun or pronominal persona, (2) the PM element is a noun in data (18) and (19) the phrase omahe Hertati and shandale Bu Zahza, has an ownership relationship that constructs animate and PR elements in the form of a human noun (personal name) or pronominal persona, and (3) the PM element of an inanimate noun and the PR element is also a inanimate noun. This can be seen in the following data.

(18) Omahe Hertati sing neng pinggir dalan kae, wingi sore ditekani pulisi.

House-poss Hertati on the side of the road yesterday visited by the police

'Hertati's house on the side of the road was visited by the police yesterday.'

(19) Shandale Bu Zahza, ditemokake karo Yahya nang ngisor bangku nomer loro.

Sandal-Poss Bu zahza found oleh Yahya di bawah bangku nomer dua.

'Ms. Zahza's sandals are found by Yahya under the chair number two.' 
(20) Sapine Pak Lurah sing ilang wingi kae, wis ketemu.

Cow-Poss the headman disappeared yesterday found

'The headman's cow that was disappeared yesterday, has been found'.

(21) Kucingku mati wingi sore, jalaran loro wis rong dina.

CatPoss died yesterday afternoon, illness two days.

'My cat died yesterday afternoon, due to illness for two days.'

(22) Aku soyo deg-degan nyawang lawang omah sing ujug-ujug nutup dewe.

'I am getting more pounding, seeing door that is closed by its own'.

$\mathrm{PM}$ in the form of a non-human noun is lifeless and the element of PR is a human noun or pronominal persona. The words omahe and sandhale are those owned by Hertati and Mrs. Zahza. Data (20) and (21) state that the PM element is in the form of animate noun and the PR element is a human noun (personal name) or pronominal persona. The word kucing and sapi are nouns owned by $-k u$ and the village chief. While in data (22)) the word lawang omah although the marker -e / -ne was not found but it has already been shown that the word pager belongs to the word mesjid, and the word lawang belongs to the word omah.

The PM element is a pretty common noun owned by an individual. This property relationship can be known from the characteristics of PM elements. The PM element is an entity that is considered reasonable owned by people. Another feature is that the PM element is an alienable entity so that its possessive construction is called alienable possession. In the view of Gerner [18] such relationships are categorized as temporal property relationships. This means that the PM element can be transferred at any time because PR has broad access to the PM element.

\section{Conclusions}

The possessive meaning in Javanese is in the polymorphemic level, phrase level, and clause level. At the polymorphemic level, possessive meaning is expressed by nouns followed by pronominal persona enclitics. The nouns in the construction act as the proprietor (PM) and pronominal persona as the owner (PR). Enclitic persona at this level includes the first, second and third pronominal enclitics. At the phrase level, possessive meaning is expressed by nouns followed by personal nouns and nouns followed by nouns. Personal pronouns act as public relations. The nouns that play the role of PR are divine nouns, animal nouns, nouns, plants, and nouns (concrete objects). Whereas at the clause level possessive meaning is expressed by verbs that occupy the predicate $(\mathrm{P})$. The verb is often called possessive verb. The nouns occupying the subject in the clause are declared as PR, and the nouns occupying the object are referred to as possessed (PM). 
In Javanese, possessive construction is found which states the relationship of ownership in the form of (1) possessive construction in which the PM element is an inanimate non-human noun and the PR element is a human noun or pronominal persona, (2) the PM element is an inanimate noun and the PR element is a human noun (personal name) or pronominal persona, and (3) PM elements are lifeless nouns and PR elements are also lifeless nouns.

\section{REFERENCES}

[1] F. Ameka, Possessive Construction in Likpe (Sekpele'). In Aikhenvald A.Y., Dixon R.M.W (Eds.) Possession and Ownership: A crosslinguistic typhologi. Oxford: Oxford University Press, pp.224, 2013.

[2] G. Storto, Possessives in Context Issues in The Semantics of Possessive Construction (disertasi). University of California, 2003.

[3] V. Vorob'jova and I. Novitskaja, Possessive Constructions in The Obdorsk Dialect of The khanti Language. Linguistica Uralica, pp.129- 150, 2018.

[4] H. Alwi, Tata Bahasa Baku Indonesia. Jakarta: Balai Pustaka, 1998.

[5] M. Ramlan, Tata Bahasa Indonesia. Yogyakarta: Andi Offset, 1989.

[6] B. Heini, Possesion, Cognitive Sources, Forces and Grammaticalization. Cambridge: Cambrige University Press, 1997.

[7] S. Peters, The Semantics of Possessives. Stanford University Dag Westerstahl Stockholm University and University of Gothenburg, 2013.

[8] T. Setiawan, Konstruksi posesif Bahasa Indonesia dalam Rubrik Surat Pembaca. Lap Penelit Mandiri, Fak Bhs dan Seni Univ Negeri Yogyakarta, 2015.

[9] Taylor, "Possession" in Concises Encyclopedia on Grammatical Categories. Cambridge : Cambridge University Press, 1999.

[10] N. Boneh and S. Ivy, Deconstructing Possession. In: Natural Language and Linguistic Theory, pp. 1-40, 2010.

[11] Y. Sulistyono, Karakteristik Alat perelatif Sing dan Kang/Ingkang serta Strategi perelatifan dalam Bahasa Jawa. Jurnal Kajian Linguistik dan Sastra. Vol. 27, no. 1, pp. 61-67, 2015.

[12] E. Suwatno, Konstruksi Posesif dalam Bahasa Jawa. Lap Penelitian, Balai Bhs Yogyakarta, 1999.

[13] Djaka Lodang magazine, volume XXII, XXIV, XXIX in 2017

[14] Panjebar Semangat Magazine, volume 29, 19, 20 from May to July 2018

[15] Sudaryanto, Metode dan Aneka Teknik Analisis Bahasa: Pengantar Penelitian Wahana Kebudayaan Secara Linguistik. Yogyakarta: Sanata Dharma University Press, 2015.

[16] Sudaryanto, Tata Bahasa Baku Bahasa Jawa. Duta Wacana University Press, 1991.

[17] Wedhawati, Tata Bahsa Jawa Mutakhir. Yogyakarta: Kanisius; 2005.

[18] M. Gerner, "The Zoom- onpossessee Construction in Kam (Dong): the Anatomy of a New Construction Type," Linguistics. Cambridge: Cambrige University Press, 2005. 